\title{
COMPRESSIBILITY CHARACTERISTICS OF BLACK COTTON SOIL ADMIXED WITH SAWDUST ASH AND LIME
}

\author{
C. C. Ikeagwuani* \\ DEPARTMENT OF CiVIL ENGINEERING, UNIVERSITY OF NigERIA, NSUKKA. ENUGU STATE - NIGERIA. \\ E-mail address: chijioke.ikeagwuani@unn.edu.ng
}

\begin{abstract}
Black cotton soil is highly notorious for its negative effect on engineering construction either as a sub grade material or material under the foundation of buildings. The engineering properties of the soil are adversely affected by the extreme poor nature of the soil. One of such properties is the compressibility of the soil. Regrettably, little emphasis has been placed on this property of the soil. To attempt to proffer solution to this problem, this research investigated the use of sawdust ash and lime on the compressibility characteristics of the black cotton soil. This was achieved by subjecting the soil to one dimensional consolidation. Other tests such as Atterberg's limits, specific gravity and particle size distribution were also carried out on the soil sample. Sawdust ash was used as additive and it was varied in $0,4,8,12,16$ and $20 \%$ by weight of black cotton soil while lime of $4 \%$ by weight of the dry soil was also added to all the mixed samples throughout the duration of the consolidation experiment after it proved to be the most effective when added initially to the black cotton soil in various percentages ranging from 0 to $10 \%$ by weight of the black cotton soil. Analysis of the results obtained from the laboratory tests conducted on the soil samples and various mix proportions show that there were significant improvements in the compressibility characteristics of the black cotton soil when a combination of 16\%SDA and 4\%lime of the weight of black cotton soil were added to it.
\end{abstract}

Keywords: Black cotton soil, compaction, consolidation, lime, sawdust ash, stabilization

\section{INTRODUCTION}

Black cotton soils are susceptible to detrimental volumetric changes with moisture $[1,2]$. They are residual deposits formed from lava or trap rocks [3], occupy mostly the arid and semi-arid regions and also cover a very large area of the world [4]. They are rich in montmorillonite which is responsible for its expansive nature but illite is also present when their parent rock is rich in potash bearing mineral [5]. The soil is problematic for engineering construction $[6,7$, $8,9]$.

The presence of this montmorillonite, which is highly responsible for the attendant shrink-swell behaviour of the soil depending on the amount of available moisture in the soil, is the root cause of the many problems such as pavement failure and excessive settlement associated with the soil. Shrinkage during the dry season often lead to surface cracks that could open up to $50 \mathrm{~mm}$ or more and several millimetres deep [10].
To tackle the problem of excessive settlement that could undermine the integrity of the foundation during construction of buildings on the black cotton soil, researchers have attempted to stabilize the soil so as to improve the geotechnical properties of the soil especially in ascertaining the compressibility of the soil. Notably among the researchers that have conducted tests on the compressibility of the black cotton soils are [11].They studied the compressibility behaviour of black cotton soil admixed with lime and Rice husk ash and found out without stating the optimum percentage of the admixture needed for the stabilization that some parameters of consolidation such as the coefficient of consolidation and coefficient of stability increases as the percentage of the admixture increases, while the coefficient of consolidation, compression index and also the swelling index decreases as the percentage of admixture increases. The maximum dry unit weight of the soil also decreases as the percentage of the 
admixture increases while the optimum moisture content (OMC) increases as the percentage of the admixture increases.

Other researchers who have worked in similar vein on the addition of the rice husk ash with lime to investigate consolidation characteristics of black cotton soil include [12, 13 14]. Their results are in agreement with [11].

Two researchers [6] studied the compressibility of compacted black cotton soil treated with rice husk ash only. Based on their findings, it was concluded that 8 percent rice husk ash will improve the compressibility of black cotton soil whether it is compacted between the dry or wet side of the optimum. The study also revealed a progressive reduction of swelling pressure and liquid limit up to the addition of $16 \%$ rice husk ash by weight of the black cotton soil.

Another researcher [15] investigated the effect of lime on the compressibility of soil. It was found that with 3 percent lime addition by weight of the soil that the compression index, coefficient of consolidation, swelling index and even the initial void ratio decreased to an appreciable level when compared with the untreated soil.

A salient point noted in the literatures reviewed above mostly showed that researchers seek to explore ways of harnessing locally sourced material like the rice husk ash for studying the compressibility of the black cotton soil. Another locally sourced material that has been used in the recent past to stabilize the black cotton is the sawdust ash by this author [16]. In this findings, it was discovered that sawdust ash of 16 percent admixed with $4 \%$ lime significantly improved the geotechnical properties of the black cotton soil. Another researcher who has used sawdust lately in stabilizing soil was [17] with significant result. Though the soil stabilized with sawdust was marine clay with high montmorillonite content.

Sawdust also known as wood dust consists of wood formed from cutting, grinding or even drilling of wood with a saw or any other similar tool [16]. Sawdust is generally being perceived as a waste because its potential has not been fully harnessed especially in this part of the world. The two known uses of sawdust in Africa, particularly in Nigeria are for cooking where it serves as fuel and also in poultry where it serves as a soft floor for the poultry birds especially during the laying of eggs. In other part of the world, especially in Europe and in America, the sawdust has been successfully converted to many important uses as fuel, wood base board among others. It is also said that the sawdust is used as fuel for burning of bricks that generates steam for the parboiling process [17].

\subsection{Sawdust Ash}

Sawdust ash is produced by the burning of sawdust into ashes in a furnace whose temperature was set at $800^{\circ} \mathrm{C}$. The sawdust used for obtaining sawdust ash is in abundance in Nigeria and many parts of the world [18]. It is generated from logging industries and they are considered mainly as organic waste making its disposal a major source of concern for the populace. Its availability, affordability combined with its pozzolanic nature has made several researchers to explore ways of using sawdust ash in the stabilization of different soil types [19, 20,21]. The findings have been encouraging and have necessitated the need to further harness its potential.

\section{MATERIALS}

\subsection{Lime}

Lime used for this study was calcium oxide ( $\mathrm{CaO})$ also known as quicklime or burnt lime [22]. It is a white, caustic, alkaline, crystalline solid at room temperature [23]. It is relatively inexpensive and it is manufactured by heating limestone, coral, sea shells, or chalk, which are mainly $\mathrm{CaCO}_{3}$, to drive off carbon dioxide. It has a melting point of $2600^{\circ} \mathrm{C}$.

\subsection{Sawdust}

The sawdust was obtained from the saw mill at timber shed in Nsukka, Nigeria. The geographical map of Nigeria shows that Nsukka is located at longitude $6^{\circ} 51^{\prime} 24^{\prime \prime} \mathrm{N}$ and latitude $7^{\circ} 23^{\prime} 45^{\prime \prime} \mathrm{E}$ [24]. It was collected with the help of a shovel from the heap of sawdust that was produced immediately and clean sawdust without a large amount of bark of a tree was selected because it has the potential of producing satisfactory result [25]. The sawdust was immediately placed in a container and then transported to the University of Nigeria, Nsukka Laboratory.

\subsection{Black Cotton Soil}

The black cotton soil was obtained from Numan in Adamawa State, Nigeria. Numan is located at latitude $9^{\circ} 29^{\prime} 10^{\prime \prime} \mathrm{N}$ and longitude $12^{\circ} 02^{\prime} 36^{\prime \prime} \mathrm{E}$ of the Nigerian geographical map. The collection of the sample was done through disturbed sampling method using the hand carved sample method. It was collected at a depth of between 0.4 to about $1.0 \mathrm{~m}$. This was done to avoid picking up any vegetative matter or debris. The sample was then placed in air-tight bags and taken to 
the geotechnical engineering section, Civil Engineering Laboratory, University of Nigeria. At the laboratory the sample was pulverized using a hammer and index properties of the soil were determined for the sample. The oxide composition of the soil was also determined.

\section{METHODS OF EXPERIMENT}

\subsection{Production of Sawdust Ash}

The collected sawdust was placed inside the furnace and burnt at a temperature set at $800^{\circ} \mathrm{C}$ for a period of about eight hours until the entire sawdust was completely reduced to ash. After the burning of the sawdust into ash, it was allowed to cool gently in the furnace. This was done to prevent the ingress of moisture before being removed. The resulting sawdust ash produced was sieved through $75 \mu \mathrm{m}$ British test sieve and placed in air-tight polythene bags until it was ready for use. Later, a representative sample of the sawdust ash was taken and examined for its oxide composition in the laboratory using the XRF.

\subsection{Experimental Procedure}

All experimental procedures in this research were carried out in accordance with the British Standard for testing of soils. The tests carried out on the natural black cotton soil and the mixture of black cotton soil + sawdust ash + lime included Atterberg's limits, specific gravity, differential free swell and consolidation. The experiment was conducted in two stages. The first stage involves the addition of lime in various percentages ranging from 0 to $10 \%$ by weight of the black cotton soil to obtain the lime percentage with the least plasticity index. The second stage is the consolidation stage, and in this stage both the lime and sawdust ash were added to the black cotton soil. The percentage of lime obtained in the first stage with the least plasticity index was maintained throughout the various mixes in the second stage. The sawdust ash added was in various percentages of 0 to $20 \%$ by weight of the black cotton soil.

\subsubsection{Atterberg's limits}

The British method [26] for determination of Atterberg's limits such as liquid limit, plastic limit and shrinkage limit was used. The Atterberg limit of the natural black cotton soil was first determined for proper classification of the soil using the American Association for State Highway and Testing organization (AASHTO) and later the Atterberg's limits for the optimum mix for BCS + SDA + lime was determined.

\subsubsection{Specific gravity}

Specific gravity of the samples was determined using the method described by [26]. The specific gravity of the natural soil sample and that of optimum mix for $\mathrm{BCS}+\mathrm{SDA}+$ lime were determined in this study.

\subsubsection{Differential free swell}

Differential free swell (DFS) test was carried out for the determination of the expansiveness of the soil. The method [27] for the determination of the differential free swell of the sample was used in this study. DFS of the natural BCS and that of optimum mix for BCS + SDA + lime were conducted.

\subsubsection{Compaction}

The standard proctor test described by [28] was employed in determination of the compaction characteristic of the natural black cotton soil and also for other mix ratio. The optimum moisture content (OMC) at which the individual maximum dry density (MDD) was attained for the various mix ratios was derived from the proctor test carried out on them.

\subsubsection{Consolidation}

Description by [29] for one dimensional consolidation was used for the consolidation test. Before carrying out the test, the sample was first air-dried and then sieved through $4.75 \mathrm{~mm}$ sieve size aperture. Consolidation was carried out on the natural black cotton soil and also on the various mix ratios.

Table 1: Index Properties of the Black Cotton Soil.

\begin{tabular}{llll}
\hline S/No & Property & Symbol & Value \\
\hline 1 & Gravel & G & $0 \%$ \\
2 & Sand & S & $12 \%$ \\
3 & Fines & Silt & $25 \%$ \\
4 & Liquid limit & Clay & $63 \%$ \\
5 & Plastic limit & $\mathrm{W}_{\mathrm{L}}$ & $84.2 \%$ \\
6 & Plasticity Index & $\mathrm{W}_{\mathrm{P}}$ & $28 \%$ \\
7 & Shrinkage Limit & $\mathrm{I}_{\mathrm{P}}$ & $56.2 \%$ \\
8 & Specific Gravity & $\mathrm{W}_{\mathrm{S}}$ & $10.4 \%$ \\
9 & Differential Free Swell & DFS & 2.33 \\
10 & Optimum Moisture & O.M.C & $38 \%$ \\
& Content & & \\
11 & Maximum Dry Density & M.D.D & $1.29 \mathrm{gm} / \mathrm{cc}$ \\
& AASHTO & & \\
12 & CLASSIFICATION & & A-7-6 [5] \\
13 & Colour & & Black \\
14 & PH & & 7.05 \\
\hline
\end{tabular}


The samples in the oedometer ring during the course of the consolidation experiment were subjected to a pressure increment of $20,40,80,200$ and $400 \mathrm{KN} / \mathrm{m}^{2}$. The height of solid method was then used to analyze the results for the void ratio, coefficient of compression, and coefficient of volume compressibility while the coefficient of consolidation was analyzed using Taylor's square root of time fitting method.

\section{RESULTS AND DISCUSSION}

\subsection{Black cotton Soil}

The results of the properties of the black cotton soil are shown in Table 1. Using the AASHTO classification system, the soil can be classified as A-7-6 from the properties shown in Table 1. Also the oxide composition of the soil was also determined for the soil as shown in Table 2 .

\subsection{Sawdust Ash}

Table 3 shows the chemical analysis of the sawdust ash. From table 3, it can be deduced that the sawdust ash is a pozzolanic material of type $\mathrm{C}$ category according to American Society of Testing and Material, ASTM C6 18 standard. A class C pozzolana has a combination of $\mathrm{SiO}_{3}+\mathrm{Al}_{2} \mathrm{O}_{3}+\mathrm{Fe}_{2} \mathrm{O}_{3}$ greater than $50 \%$ and a loss on ignition to be less than $6 \%$.

\subsection{Atterberg's Limits Result}

Table 4 shows the values of the plastic limit and plasticity index obtained for various percentages of lime added by weight of the black cotton soil. As shown in the table, the lime added was in various percentages of $0,2,4,6,8$ and $10 \%$ by weight of the sawdust ash. The result clearly shows that $4 \%$ lime addition to the black cotton soil produced the least plasticity index and thus this value was maintained during the consolidation stage of the experiment. The result is in consonant with that obtained by so many researchers who have worked on the stabilization of black cotton soil with lime. They discovered that for effective result of the stabilization of black cotton soil with lime, the lime should vary between $3-5 \%[30,31$, $32,33]$.

\subsection{Compaction Result}

The relationships between the Maximum Dry Density and Optimum Moisture Content against \%SDA are shown in Figure 1. As seen from Figure 1, there was a progressive increase in the optimum moisture content and gradual decrease in the maximum dry density. A similar trend was observed by $[6,14,22]$ when admixture was added to the black cotton soil. The progressive increase observed in the OMC results from the soil forming a larger and coarser mixture with the additive and this process normally require additional water to be absorbed by the SDA. Also, the reduction in the maximum dry density could be attributed to the ability of the sawdust ash to coat the particles of the black cotton thereby resulting in the formation of larger particles by the bond particles ultimately generating a large void and this leads to the reduction of the maximum dry density.

\subsection{Void Ratio}

Figure 2 shows the relationship between Void Ratio against Applied Pressure. The trend of the graph for void ratio against applied pressure appears similar for all the curves. During the loading stage of the samples, the void ratio was found to decrease as the applied pressure was increased up to a maximum applied pressure where partial reversal occurred for all the mixtures. Interestingly, the $16 \% \mathrm{SDA}+4 \%$ lime combination has the lowest void ratio as compared to other SDA + lime combinations. The likely reason for this observed trend could be that the mixture quickly undergoes pozzolanic action with the soil, thus effectively decreasing the void ratio in the soil sample.

Table 2: Oxide Composition of the Black Cotton Soil

\begin{tabular}{lllllllllllll}
\hline Oxides & $\mathrm{Al}_{2} \mathrm{O}_{3}$ & $\mathrm{SiO}_{2}$ & $\mathrm{SO}_{3}$ & $\mathrm{P}_{2} \mathrm{O}_{5}$ & $\mathrm{Na}_{2} \mathrm{O}$ & $\mathrm{K}_{2} \mathrm{O}$ & $\mathrm{CaO}$ & $\mathrm{MgO}$ & $\mathrm{TiO}_{2}$ & $\mathrm{Fe}_{2} \mathrm{O}_{3}$ & $\mathrm{MnO}$ & L.O.I \\
\hline Chem. composition (\%) & 9.81 & 60.43 & $<0.001$ & $<0.001$ & 3.42 & 0.98 & 2.96 & 1.46 & 2.32 & 0.56 & 15.47 & 2.45 \\
& & & & & & & & & & & \\
\hline
\end{tabular}

Table 3: Chemical Composition of the Sawdust ash

\begin{tabular}{lllllllllllll}
\hline Oxides & $\mathrm{Al}_{2} \mathrm{O}_{3}$ & $\mathrm{SiO}_{2}$ & $\mathrm{SO}_{3}$ & $\mathrm{P}_{2} \mathrm{O}_{5}$ & $\mathrm{Na}_{2} \mathrm{O}$ & $\mathrm{K}_{2} \mathrm{O}$ & $\mathrm{CaO}$ & $\mathrm{MgO}$ & $\mathrm{TiO}_{2}$ & $\mathrm{Fe}_{2} \mathrm{O}_{3}$ & $\mathrm{MnO}$ & $\mathrm{LOI}$ \\
Chemical composition (\%) & 14.30 & 53.39 & 0.85 & 2.95 & 1.00 & 8.43 & 7.20 & 3.30 & 0.05 & 2.64 & 0.41 & 5.48 \\
\hline
\end{tabular}

Table 4: Values of plasticity index and plastic limit for different percentages of lime added to the black cotton soil

\begin{tabular}{lllllll}
\hline Atterberg's limits (\%) & 0 & 2 & 4 & 6 & 8 & 10 \\
\hline Plastic Limit (\%) & 28.0 & 10.8 & 18.9 & 10.9 & 16.9 & 14.9 \\
Plasticity index (\%) & 56.2 & 42.2 & 30.1 & 42.1 & 61.0 & 66.1 \\
\hline
\end{tabular}




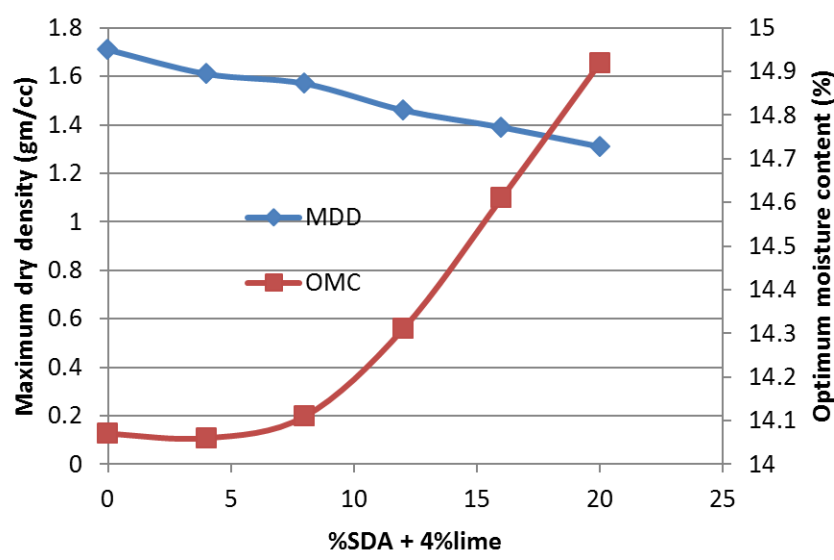

Figure 1: Maximum Dry Density and Optimum Moisture Content against \%SDA

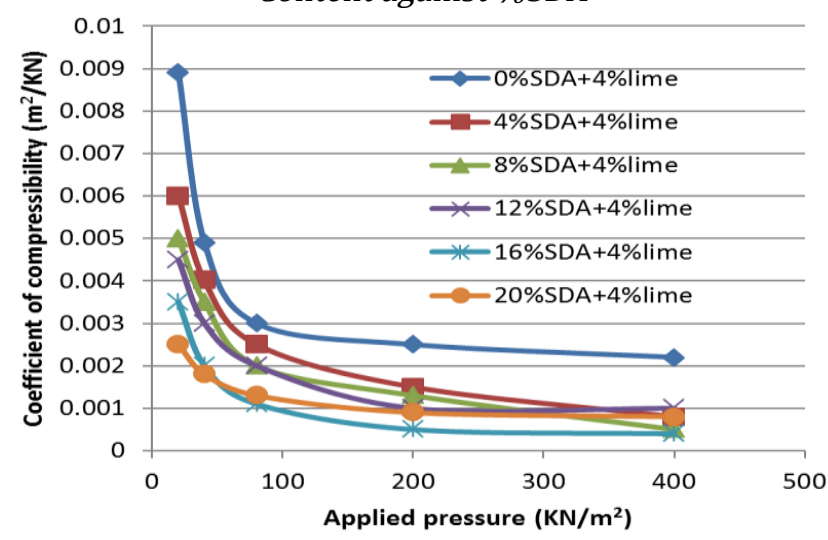

Figure 3: Coefficient of Compressibility against Applied Pressure

\subsection{Coefficient of Compressibility}

Figure 3 graph shows the coefficient of compressibility against the applied pressure. It can be seen from the figure that the shape of the curves for all mixed ratio appears similar as well. At the early stage of the loading increment there was a sharp decrease in the coefficient of compressibility for all curves. This sharp decrease in the coefficient of compressibility was as a result of the quick expulsion of air from the voids of the soil samples. Further decrease, though marginal, was as a result of the pozzolanic action occurring between the mixture and the soil particles. Again, it can be seen that the combination of $16 \%$ SDA $+4 \%$ lime proved to be most effective.

Figure 4 shows the coefficient of compressibility against the mix ratio. The graph for each of the pressure loading was found to decrease from 0 to about $16 \%$ increase of the sawdust ash $+4 \%$ lime mixture and a slight increase was observed shortly after that. Also, with a higher increase in pressure comes a corresponding decrease in the coefficient of compressibility. The observed trend in the graph could be as a result of reduction of air in the voids and also a rapid rearrangement of the soil particles at the

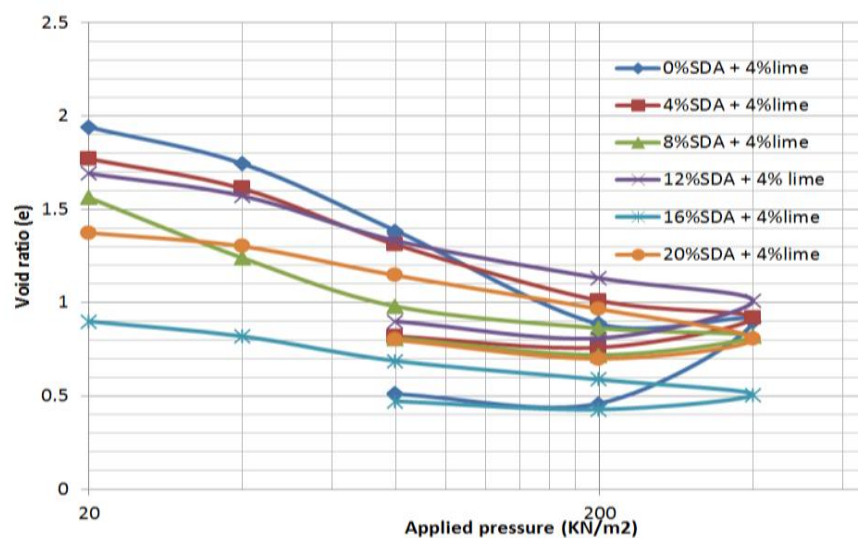

Figure 2: Void Ratio against Applied Pressure

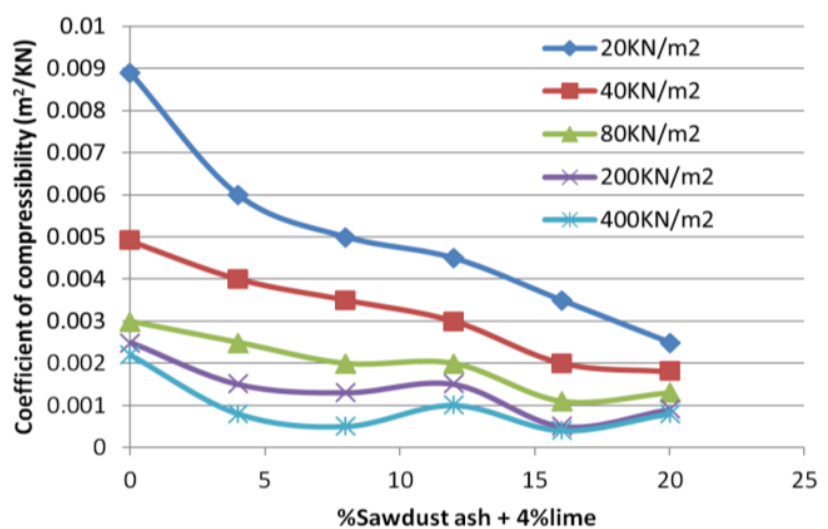

Figure 4: Coefficient of Compressibility against \%Sawdust Ash

point of the $16 \%$ sawdust ash and $4 \%$ lime mixture thus, making the soil particles more compact and less compressible.

\subsection{Coefficient of Volume Compressibility}

The graphs of figures 5 and 6 are somewhat similar to that of figures 3 and 4 respectively. The reason stated for the coefficient of volume compressibility can also be adduced to be responsible for the shape of the graph of coefficient of volume change, $\mathrm{M}_{\mathrm{v}}$. Both the coefficient of volume compressibility and coefficient of volume change are used interchangeably. In practice however, the coefficient of volume change is more commonly used than the coefficient of compressibility.

\subsection{Coefficient of Consolidation}

The coefficient of consolidation against the \%SDA graph in figure 7 clearly shows that there was a significant decrease in the values of the coefficient of consolidation as the percentage of the sawdust increases till it got to $16 \%$ increase in the sawdust. This trend is similar for all the curves as shown in figure 7. 


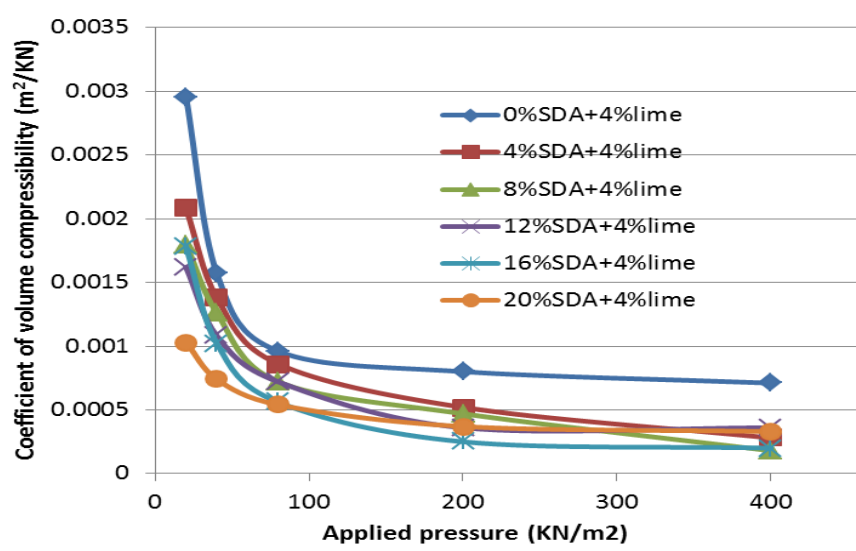

Figure 5: Coefficient of Volume Compressibility against Applied Pressure

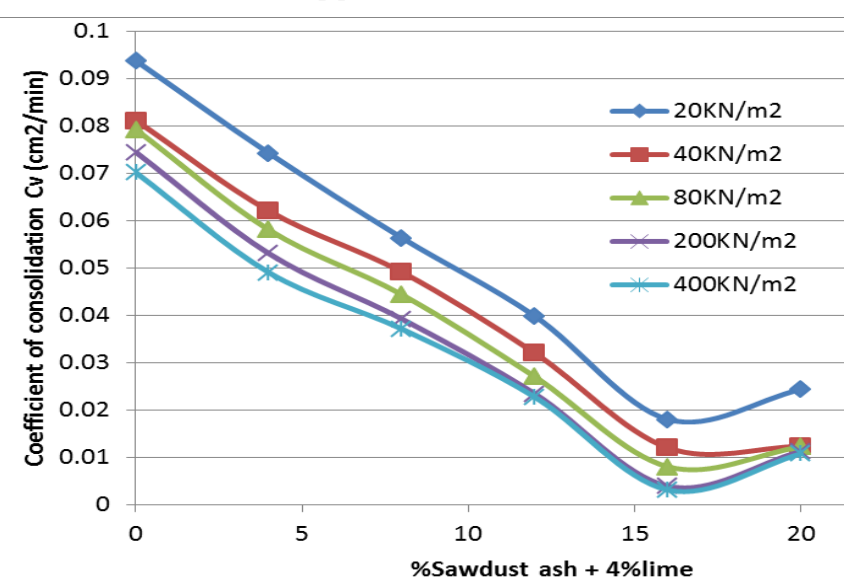

Figure 7: Coefficient of Consolidation against $\% S D A$

The reduction in the coefficient of consolidation could be due to the rearrangement of the soil particles and the pozzolanic reaction taking place between the soil particles and the mixture according to [22] and this is said to be attributed to the mechanical and physicochemical effects in agreement with [34] till it got to the fixed point which in this case it was at $16 \%$ SDA mixture. Further increase in the \%sawdust after $16 \%$ SDA increase, results in the formation of larger particles and ultimately the larger voids spaces. Figure 8 shows the relationship between the coefficient of consolidation and the applied pressure. It is evident from the curves shown for each of all the mix ratios, a decrease in the coefficient of consolidation is observed with increase in the applied pressure and the coefficient of consolidation is found to be smaller in the $16 \%$ SDA mix ratio. This result is in conformity with that observed for other parameters.

\subsection{Compression Index}

A gradual decrease in the value of the compression index was observed in figure 9 as the \%SDA was increased. The reduction observed could be attributed

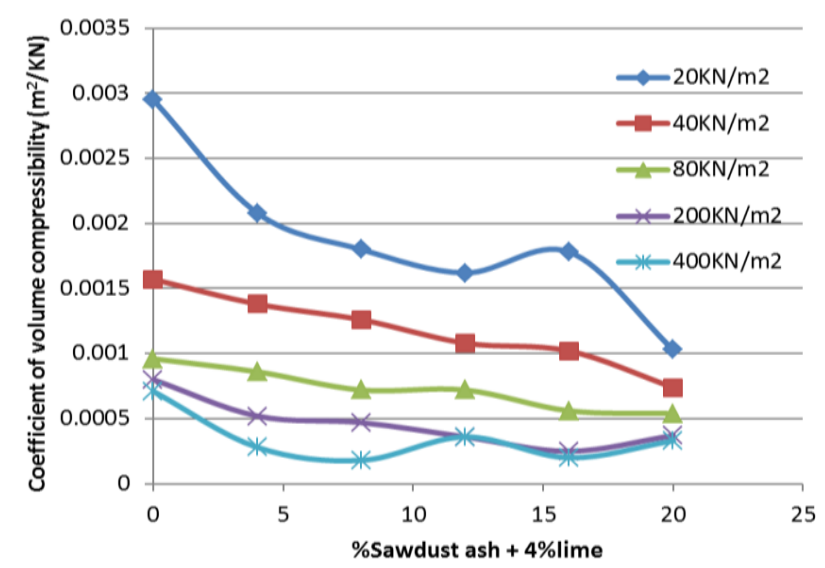

Figure 6: Coefficient of Volume Compressibility against $\% S D A$

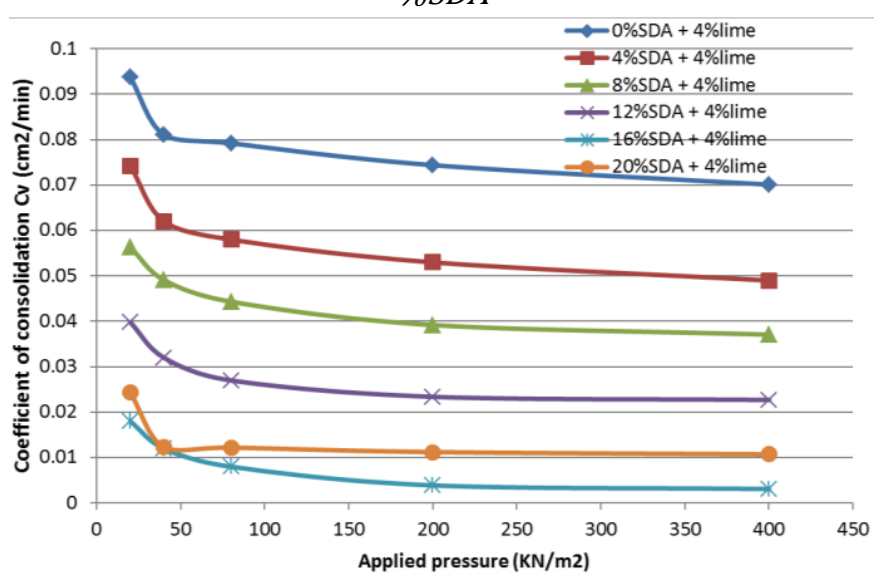

Figure 8: Coefficient of Consolidation against Applied pressure

to the increased formation of pozzolanic products that was increased within the existing pore spaces due to the physicochemical changes [6].

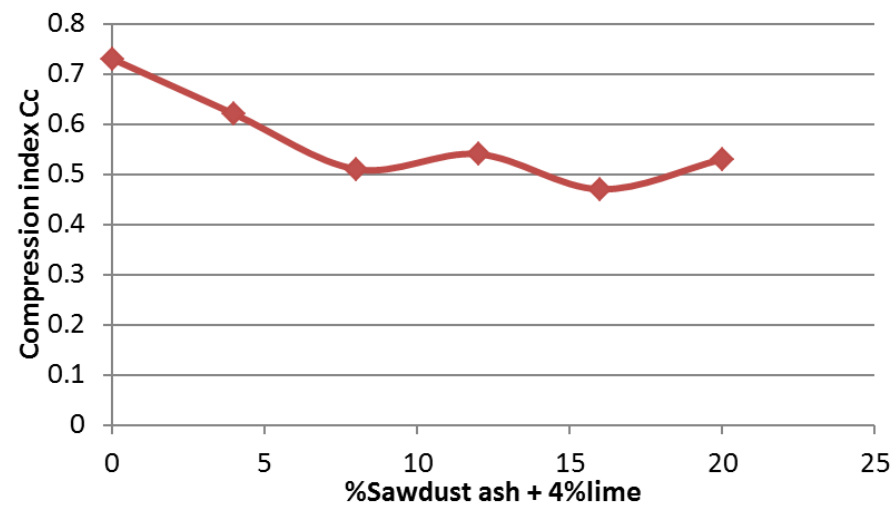

Figure 9: Compression Index against \%SDA

\section{CONCLUSION}

Investigation into the compressibility characteristics of black cotton soil has indicated that it can achieve an optimum performance in its useful life if admixed with a combination of $6 \%$ SDA and $4 \%$ lime by weight of the black cotton soil. The result obtained from this 
research work agreed with that of [16] for the stabilization of black cotton for use as subgrade material. Further test carried out included the specific gravity, which improved from 2.34 to 2.37 , liquid limit, which decreased from 84.2 to $40.6 \%$ and plastic limit, which increased from 28.0 to $33.3 \%$. Thus, the overall plasticity index was down from 56.2 to $7.3 \%$. The differential free swell also improved with a decreased from 79 to $25.2 \%$

\section{ACKNOWLEDGEMENT}

I sincerely wish to thank Agu Jude Nnamdi and Okorouga Franklin for their tremendous effort in assisting me to conduct some of the experiment in the laboratory.

\section{REFERENCES}

[1] VenkaraMuthyalu, P., Ramu,K. and Prasada, G. V. "Study on performance of chemically stabilized expansive soil," International Journal of Advances in Engineering \& Technology, vol. 2, no. 1, , pp. 139148, (2012).

[2] Bairwa, K., Saxwna, A. K. and Arora, T. R. "Effect of lime and fly ash on engineering properties of black cotton soil," International Journal of Emerging Technology and Advanced Engineering, vol. 3, no. 11, pp. 535-541. (2013).

[3] Purushothama, P. R. Ground Improvement Techniques. New Delhi, India: Firewall Media, (2005).

[4] Verma, S.K. and Maru, S. "Behaviourial study of expansive soils and its effect on structures - A review," International Journal of Innovations in Engineering and Technology, vol. 2, no. 2, pp. 228238. (2013).

[5] Tamhane, R. V. and Namjoshi, N. C. "A comparative study of black soils formed from different parent rocks," J. Indian Soc. Soil Sci., vol. 7, 1959, pp. 49-68]

[6] Eberemu, A. O. and H. Sada, H. "Compressibility characterisitics of compacted black cotton soil treated with rice husk ash," Nigerian Journal of Technology, vol. 32, no. 3, pp. 507-521. (2013).

[7] Koteswara R. D., Pranav, P. R. T. and Venkatesh, G. "A laboratory study on the efficacy of rice husk ash and potassium chloride for the stabilization of expansive soil," International Journal of Engineering Science and Technology, vol. 4, no. 1, , pp. 97-108. (2012).

[8] Oriola, F. and Moses, G. "Groundnut shall ash stabilization of black cotton soil," EJGE, vol. 15, no. Bund E, , pp. 415-428. (2010).

[9] Kanawi, M. A. and Kamel, A. O. "Durability of expansive soil treated by chemical additives,"
International Journal of Engineering and Innovative Technology, vol. 3, no. 1, pp. 315-319 (2013).

[10] Osinubi, K. A., Oyelakin, M. A. and Eberemu, A. O. "Improvement of Black Cotton Soil with Ordinary Portland Cement - Locust Bean Waste Ash Blend," (2011).

[11] Narasihma R. A. V., Penchalaiah, B. and Chittranjan, M. "Compressibility behaviour of black cotton soil admixed with lime and rice-husk ash," International Journal of Innovative Research in Science,Engineering and Technology, vol. 3, no. 4, , pp. 11473-11480. (2014).

[12] Sivanna, G. S., Srinivasan, T., Subramanyam, N. and Sampath, K. T. "Consolidation characteristics of black cotton soil mixed with lime and rice-husk ash admixtures," in Proc.1st National Symposium on Expansive Soils, H.B.T.I., , Kanpur, (1977).

[13] Ramaiah., B. K., Shivananda, M. and Satyapriya, C. K. "Stabilization of black cotton soil with lime and ricehusk ash," in Annual General Body Meeting of Indian Geotechnical Society, Indian, (1972).

[14] Muntohar, A. S. "Utilization of uncontrolled burnt Rice Husk Ash in soil improvement," Demensi Teknik Sipil, vol. 4, no. 2, , pp. 100-105. (2002).

[15] Amiralian, S. Chegenizadeh, A. and Nikraz, H. "Laboratory investigation on the effect of lime on compressibility of soil," in Internationational Conference on Civil and Architectural applications (ICCAA'2012), Phuket, Thailand, (2012).

[16] Ikeagwuani, C. C. "Stabilization of black cotton soil with sawdust ash and lime for subgrade,"M.S. thesis, Dept of Civil Eng., Univ. of Nigeria, Nsukka, Enugu, Nigeria, (2013).

[17] Koteswara R. V., Anusha, M., Pranav, P. R. T. and Venkatesh, "A Laboratory study on the stabilization of marine clay using sawdust and lime," International Journal of Engineering Science and advanced technology, vol. 2, no. 4, , pp. 851-862. (2012).

[18] Tyagher, S. T., Utsev, J. T. and Adagba, T. "Suitability of saw dust ash-lime mixture for production of sandcrete hollow blocks," Nigeria Journal of Technology, vol. 30, no. 1, , pp. 79-84. (2011).

[19] Osunubi, K. J.,Edeh, J. E. and Onoja, W. O. "Sawdust Ash Stabilization of Reclaimed Asphalt Pavement," Journal of ASTM International, vol. 9, no. 2, (2012).

[20] Edeh, J., Agbede, I. and Tyoyila, A. "Evaluation of Sawdust Ash-Stabilized Lateritic Soil as Highway Pavement Material," J. Mater. Civ. Eng., vol. 26, no. 2, , pp. 367-373. (2014).

[21] Okunade, E. A. "The Effect of Wood Ash and Sawdust Admixtures on the Engineering Properties of a Burnt Laterite-Clay Brick," Journal of Applied Science, vol. 8, no. 6, pp. 1042-1048. (2008). 
[22] Ikeagwuani, C. C., Nwoji, C. U. and Okonkwo, C. "Compressibility Characteristics of Lateritic Soil Admixed with Coconut Husk Ash and Lime," International Journal of Engineering Research \& Technology, vol. 4, no. 11, , pp. 288-295. (2015).

[23] "Wikipedia," The free encyclopedia, [Online]. Available: $\quad$ http://en.wikipedia.org/wiki/ Calcium_oxide. [Accessed 28 April 2016].

[24] "Wikipedia," The free encyclopedia, [Online]. Available: http://en.wikipedia.org/wiki/Nsukka, 2014. [Accessed 28 April 2016].

[25] Olutogbe, F. A. "Investigations on sawdust and palm kernel shells as aggregate replacement," $A R P N$ Journal of Engineering and Applied Sciences, vol. 5, no. 4, , pp. 7-13. (2010).

[26] British Standard Institute, Methods of testing soils for civil engineering purposes, BS 1377, Part 2,(1990).

[27] Indian Standard, Indian Standard code of practice for design and construction of pile foundation, IS 2911, Part 3, (1980).

[28] Bristish Standard Institute, Methods of testing soils for civil engineering purposes, BS 1377, Part 4, (1990).
[29] British Standard Institute, Methods of testing soils for civil engineering purposes, BS 1377, Part 6, (1990).

[30] Nadgouda, K. A. and Hegde, R. A."The effect of lime stabilization on properties of black cotton soil," in Indian Geotechnical Conference, Mumbai Chapter \& IIT Bombay, (2010).

[31] Ranganatham, "Soil structure and consolidation characteristics of black cotton clay," Geotechnique, vol. 11, no. 4, pp. 333-338. (1961).

[32] Subba R. K. V., Narasimha R. S. and Sankaran, K. S. "Compressibility Behaviour of Lime treated soils," in Indian Geotech Conf (IGC -8), Madras, (1983).

[33] Akawwi, E. and Al-Kharabsheh, A. "Lime stabilization effects on geotechnical properties of expansive soils in Ammam Jordan," Electronic Journal of Geotecnical Engineering, (2002).

[34] Robinson, R. G. and Allam, M. M. "Effect of clay mineralogy on the coefficient of consolidation," Clay and clay minerals, vol. 46, no. 5, , pp. 596-600. (1998). 